\title{
Analysis of Rabbit fillet business with the business model canvas approach at Azhar Farm
}

\author{
Siti Azizah ${ }^{1 *)}$ and Hafidz Budi Handoko ${ }^{1)}$ \\ 1) Faculty of Animal Science, Brawijaya University, Jl. Veteran, Ketawanggede, Kec. \\ Lowokwaru, Kota Malang, Jawa Timur, Indonesia, 65145
}

Submitted: 28 September 2020, Accepted: 21 November 2020

\begin{abstract}
The Azhar Farm rabbit fillet business is currently facing various obstacles to maintain sustainability and expand the product marketing area, the Azhar Farm company is demanded to be able to improve performance by improving its previous business model.This research was conducted to find a general description of the business, the business model of canvas that has been used, and create improvement recommendations for business models of the rabbit fillet business at Azhar Farm. This type of research is descriptive. The Business Model Canvas uses a qualitative approach, while the SWOT uses a quantitative approach with data collection conducted for two and a half months from January to March 2020. This research is focused on the level of renewal of information obtained from the real situation. It provides recommendations for business models improvement with the Business Model Canvas tool by looking at Azhar Farm through the nine elements of BMC. The SWOT analysis results show that the value of the axis $(\mathrm{X})$ of 0.68 and the value of the axis $(\mathrm{Y})$ of 0.97 reflect a positive state and are in quadrant I with the strategy that must be implemented is aggressive.In the rabbit fillet,Azhar Farm also needs to make improvements to the nine elements of BMC to be able to compete and expand the market and maintain stability in the business.
\end{abstract}

Keywords: Rabbit farm; business model; strategy; swot

*Corresponding Author: siti.azizah@ub.ac.id 


\section{INTRODUCTION}

Indonesia is a country rich in natural and human resources with excellent prospects for animal husbandry. One of the livestock businesses that have increased is broiler rabbits. Rabbits have the potential to be bred because they can breed quickly and are easily adaptable. The rabbit population is currently $80 \%$ spread across the island of Java. One of the rabbit production areas in Batu City, which has a population of 25,148 (BPS, 2016).

The current demand for rabbit meat on a regional scale is high, but specific markets make it difficult for farmers to achieve it. According to Masyhuri Azhar, one of the heads of the rabbit breeders association in Batu City, as well as the owner of Azhar Farm, interviewed Suryamalang.com (2018), stated that the demand for rabbit meats in Batu City and its surroundings reaches $300 \mathrm{~kg}$ per week. Still, the available stock only $100-150 \mathrm{~kg}$ per week,so, to sufficient market needs, must bring in supplies from outside the area, which causes increasingly fierce price competition.

In high business competition, many farmers survived or closed down. A rabbit farm business that closed down is caused by an imbalance between the production costs incurred and the income generated. To increase the revenue of rabbit breeders, innovation, and sales strategies for products with high economic value are needed. Azhar Farm is one of the broiler rabbit farms in Batu City, which until now, exists to produce rabbit fillets. Its products have a high selling value compared to without slaughtering rabbits. But now Azhar Farm has problems in marketing products widely and sustainably.

This proves that innovation is not enough; it requires internal and external analysis as well as appropriate business strategies and models to be able to maintain existence and win the fierce business competition. This research was conducted to find a general description of the business. This business model has been applied, and create recommendations for improvement business models for the rabbit fillet business at Azhar Farm.

\section{MATERIALS AND METHODS Research time and location}

The field research was conducted from January to March 2020. The location taken was determined intentionally at the center of the Azhar Farm broiler rabbits in Bumiaji Village, Batu City. Azhar Farm was chosen because it is one of the dominant and continuous rabbit breeders producing rabbit fillets. Also, Azhar Farm has obstacles in managing the business because it is still relatively new for one year in running the rabbit fillet business and in the coming years plans to expand the market for the rabbit breeding business so that it becomes strategic as a research object to study the right opportunities and strategies in developing the rabbit business. Besides, the limitations of geography andpractical such as time, cost, and labor, are also considered in this research.

\section{Research Tools and Materials}

The tool used in this research was a questionnaire that referred to 9 elements of the Business Model Canvas and several other supporting devices such as stationery and camera. The material used was one typed New Zealand White rabbit that was slaughtered during the observation to determine the percentage of rabbit fillet produced.

\section{Types of Research}

Research conducted in descriptive type, the Business Model Canvas uses a qualitative approach while the SWOT uses a quantitative approach. The things that included in the qualitative descriptive approach are the study of aspects of BMC that affect the rabbit fillet business both internally and externally. In contrast,the things included in the quantitative approach is the SWOT study of Azhar Farm's condition in managing the rabbit fillet business. This research is focused on the level of renewal of information obtained 
from the field situation and business strategy.

\section{Methods of Determining Informants}

The determination of informants is carried out through specific considerations and objectives. Internal informants taken were business owners and employees of Azhar Farm. They were chosen because they had the knowledge, expertise, competence, and were directly involved in the rabbit business from the beginning to the research conducted.So, it can represent the current condition of the rabbit fillet business. Consumers who are selected externally in this business are rabbit satay sellers in the Batu City area.The main reason for the selection of stakeholders is based on the consideration of researchers, satay sellers as consumers who have been buying rabbit fillets.Retrieval of information about internal informants is more emphasized on how business processes are carried out using BMC, while externals are more focused on product assessments, hopes, and desires of the products purchased and services needed.

\section{Data Types and Sources}

The data used are qualitative data based on nine elements in the Business Model Canvas with data sources derived from primary and secondary data. Field data retrieval is done by interview, observation, and documentation.

\section{Data Analysis}

Data analysis carried out referring to the Moleong theory (2012) are:

1. Data collected obtained from various sources through interviews.

2. Data Reduction, making abstraction in the form of a summary core research, processes, and statements following the objectives of the research.

3. Categorization isa compilation of research data into categories arranged based on points of view, opinions, or certain criteria that have been determined.

4. Data Validity Check, carried out to reduce data gaps and show that the content of research data is truly valid using the Triangulation technique, which uses things other than data, such as interviews, to show the validity of the data in the research. It uses reference material in each step of the research that can be seen again as a database as well as Doing a member checks, namely checking the data back to the interviewee.

\section{RESULT AND DISCUSSION Azhar Farm Rabbit Overview}

Azhar Farm was established and occupy land in Binangun Hamlet in 2017 with a division of production for rabbit meat, breeding, feed, and processing of livestock products. Azhar Farm raising New Zealand White Rabbit species, this species was chosen because it has a fast growth rate, carcass quality, fertility, birth rates, and good parenting abilities of their offspring (Widitania, Yon and Sri, 2013). Azhar Farm runs the business from upstream to downstream, starting from the seeding, feed making, raising, harvesting, slaughtering, and processing to marketing. Azhar Farm currently has around 300 rabbits with rabbit fillet production capacity per week, reaching $40-50 \mathrm{~kg}$.

The main products produced by Azhar Farm are carcasses, fillets, feed, seeds, and rabbits that are ready to be slaughtered. Azhar Farm uses a battery cage in maintaining and treating waste used as biogas.In 2019 Azhar Farm strengthens its main products are feed and meat. In addition to selling feed in three types, which starter, grower, and finisher phases, Azhar Farm also began selling rabbit fillets. In 2020 to expand the reach of Azhar Farm manages the legal aspects and continues to expand the marketing of rabbit fillets.

\section{Identify the rabbit fillet business model with the Business Model Canvas Approach}

The first step of this research was to identify the rabbit fillet business model, which refers to the nine components of the Business Model Canvas. The business model is a method used by a company to make money where the company operates 
(wheelen and hunger, 2010). According to Euis et al. (2014), BMC has nine elements that are important to identify business models at KNM Fish Farm and identify elements that need improvement to help business sustainability in the future. Osterwalder and Pigneur (2012) make "Nine Building Blocks" while nine blocks consist of (1) Customer Segments, (2) Customer Relationship, (3) Value Propositions, (4)
Channels, (5) Revenue Streams, (6) Key Activities, (7) Partners, (8) Resources, (9) Cost Structure. The compilation of the BMC rabbit fillet business is based on the results of interviews conducted with internal respondents and observations by researchers. The rabbit fillet business models that have been applied by Azhar Farm with the Business Model Canvas approach can be seen in Figure 1.

\begin{tabular}{|c|c|c|c|c|}
\hline $\begin{array}{c}\text { Key } \\
\text { Partners }\end{array}$ & Key Activities & Value Proposition & $\begin{array}{c}\text { Customer } \\
\text { Relationship }\end{array}$ & $\begin{array}{l}\text { Customer } \\
\text { Segments }\end{array}$ \\
\hline Breeder Partner & Breeding & $\begin{array}{l}\text { High Protein, Low } \\
\text { Fat, and Low }\end{array}$ & $\begin{array}{l}\text { Personal } \\
\text { Communication }\end{array}$ & Satay Sellers \\
\hline $\begin{array}{l}\text { Feed Production } \\
\text { Partners }\end{array}$ & Feed Production & Cholesterol & $\begin{array}{l}\text { using Whatsapp } \\
\text { application }\end{array}$ & Individuals \\
\hline Fillet Distributors & Raising/Cultivating & $\begin{array}{l}\text { Easy to process } \\
\text { into satay }\end{array}$ & & \\
\hline Key Resources & Harvesting & & Channel & \\
\hline $\begin{array}{l}\text { New Zealand } \\
\text { White Rabbits }\end{array}$ & $\begin{array}{l}\text { Slaughtering and } \\
\text { Processing }\end{array}$ & Long Shelf Life & $\begin{array}{l}\text { Expo, seminar, } \\
\text { bazaar }\end{array}$ & \\
\hline Rabbit Feed & Marketing & & Direct Supply & \\
\hline $\begin{array}{l}\text { Physical, } \\
\text { financial and } \\
\text { HR resources }\end{array}$ & & & $\begin{array}{l}\text { Word of mouth } \\
\text { promotion } \\
\text { Through the } \\
\text { Facebook } \\
\text { application }\end{array}$ & \\
\hline \multicolumn{3}{|c|}{ Cost Structure } & \multicolumn{2}{|c|}{ Revenue Streams } \\
\hline \multicolumn{3}{|c|}{$\begin{array}{l}\text { Drugs, Vitamins, and Vaccines } \\
\text { Cultivation equipment } \\
\text { Land and Building Tax Payment and Electricity payment } \\
\text { Employee Salary } \\
\text { Raise of cultivation Facilities and Equipment }\end{array}$} & \multicolumn{2}{|c|}{$\begin{array}{l}\text { Sales of Rabbit Fillets } \\
\text { Carcasses } \\
\text { Feeds } \\
\text { Seeds } \\
\text { Rabbit ready to be slaughtered } \\
\end{array}$} \\
\hline
\end{tabular}

Figure 1. BMC of Azhar Farm rabbit fillet business

\section{SWOT Analysis}

This analysis is based on logic, which can maximize strengths and opportunities while simultaneously minimizing weaknesses and threats. According to Rangkuti (2005), SWOT analysis is the systematic identification of various factors to formulate a company's strategy, and SWOT analysis is a popular model for situation analysis. The determination of the SWOT analysis points is carried out on the basis results of interviews with internal and external respondents also the results of observations by researchers. The results of the rabbit fillet business analysis in the IFAS calculation obtained a score for Strength (S) 1.60 and a score for Weakness (W) 0.92. While the analysis results in the EFAS calculation obtained a score for the Opportunity factor (O) 1.91 and a score for the Threat factor $(\mathrm{T}) 0.94$. The next step is to calculate the coordinates of the rabbit 
fillet business development strategy using internal and external factor calculations by using a SWOT analysis diagram. Based on the calculation results of the SWOT analysis, the $(\mathrm{X})$ axis is 0.68 , and the $(\mathrm{Y})$ axis value is 0.97 so that it reflects the quadrant $\mathrm{I}$ at the positive coordinates. The diagram of the results SWOT analysis can be seen in Figure 2. The identification results support an aggressive strategy. The aggressive strategy is a strategy that is done by using strengths to look for available opportunities and manage weaknesses and threats (Rangkuti, 2005).

The results of previous studies conducted by Supranto (1997), when the total difference is in quadrant 1 , states that the company is in the best condition, it is very possible to be able to expand, increase growth and achieve maximum progress. The conclusion is that Azhar Farm has good internal and external strength. Therefore, the right business development strategy is needed.

The next step is to identify business development strategies using the SWOT matrix based on Strengths (S), Weakness (W), Opportunities (O), and Threats (T) owned by Azhar Farm. Based on the SWOT matrix analysis, which is classified into four alternative strategies that can be applied are the SO, WO, ST, and WT strategies. It can be used to develop the rabbit fillet business so that it can grow broadly and sustainably. It tends to be more appropriate to use $\mathrm{SO}$ and or WO strategies. It is a strategy to maximize strengths to seize opportunities that are wide open and minimize gaps in weaknesses to take advantage of opportunities.

\begin{tabular}{|l|l|l|}
\hline \multicolumn{1}{|c|}{$\begin{array}{l}\text { Quadrant III } \\
\text { Change Strategy0,97 }\end{array}$} & $\begin{array}{c}\text { Quadrant I } \\
\text { Aggressive }\end{array}$ \\
\hline $\mathrm{X}$ & $\begin{array}{c}\text { Quadrant IV } \\
\text { Defense Strategy }\end{array}$ & $0,68 \quad \begin{array}{c}\text { Quadrant II } \\
\text { Diversification Strategy }\end{array}$ \\
\hline
\end{tabular}

Figure2.The diagram of the results SWOT analysis

\section{Recommendation of Business Model Improvements Using Business Model Canvas}

To make the strategies generated from a series of SWOT analysis processes easier to understand and apply, then input data into the BMC. Business Model Canvas has the advantage of successfully changing the complex business model concept to be simple (Muller et al. 2011). Improvements for each element of the Azhar Farm rabbit fillet Business Model Canvas are:

\section{Customer Segment}

Azhar Farm has the advantage that the location is close to Batu Tourism City, which has many tourists and culinary specialties of Batu City. Azhar Farm is also close to Malang City, which is known as an education city with a high number of students and diverse food needs. The city also has many hotels and tourists who visit for tourism purposes or attend graduation events at many universities and institutes located in Malang. There are malls as shopping places that can be used to find customers and on a large scale. New market segmentation is:

\section{Supermarket}

Almost every day, people visit the supermarket to shop for daily needs. Sales brands and variations also licenses are needed so that products can be sold and target consumers.

2. Hospitality

The hotel requires the supply of raw materials for guests who are staying overnight. The famous city of Batu with rabbit satay makes the menu of rabbits has 
an attraction to be enjoyed. This is an opportunity to reach hospitality as new market segmentation. The entry of rabbits in the hotel dining menu is also promotional to be familiar and increasingly known by tourists.

\section{Catering Entrepreneurs}

Dense population in the city and many events that are often done at home scale, campuses, companies to government agencies make the catering business crowded and get lots of orders. This segmentation is entirely rational because the distinctive rabbit fillet status and not much circulation in other cities make the attraction for catering entrepreneurs and consumers.

4. Wedding Organizer

This Wedding Organizer usually takes care of all the needs of the bride and recommendsunique dishes selected by many brides. This makes it a business opportunity for rabbit fillets to become a special menu for any wedding.

5. Visitors

Batu city, which is known as one of its special products, is rabbit meat that makes visitors curious. Processing or selling products with different quality variations and attractive packaging require collaboration with restaurants or souvenir shops around Batu Tourism City.

6. Online

Azhar Farm needs to take advantage of this online business to reach consumers throughout Indonesia in large numbers and continuously. Collaboration with marketplaces to expand marketing chains. Besides, cooperation partners with the expedition also need to provide refrigerators for the delivery of rabbit fillets

\section{Value Proposition}

According to Morris (2009); Horvath et al. (2016) said that a successful business model must have the advantage of a value proposition that is used as a competitive advantage to improve relationships between elements of the business model. The advantages of the product must be increased according to the needs and desires of consumers. These advantages include:

1. Cooperation packages with special prices and minimum purchase.

This package, besides indirectly, binds the customer so as not to turn away. The package is given by considering the estimated cost and production of rabbit fillets.

2. Build brands, catalogs, and sales weight variations.

It is needed to consider the brand so that every search is focused on the brand name. Also, a catalog is needed so that consumers can choose what they want to buy, and it is easy to make comparisons and view existing products. Sales weight variations also need to be considered so that consumers can buy according to the needs they want.

\section{Channels}

The addition of channels that can be considered are :

\section{Governmentagencies}

The agency has the resources and duties to help MSMEs so that they can be used as partners and promotional media through various activities. Besides proposing regulations to provide a mandatory menu for hotels in the Batu City area with rabbit products is one way to reach consumer segmentation in hospitality as well as promoting rabbit farm.

2. Online Marketer

Azhar Farm should consider recruiting or building partnerships with youth to reach online market segments, especially outside the greater Malang area, through online marketing.

3. Offline Marketer outside the city of Malang

Azhar Farm focuses on marketing in Batu City and has not yet reached markets outside the Greater Malang area. The addition of these partners needs to be considered in selling rabbit fillet products widely and sustainably. 


\section{Promotion With Social Media Networks}

It is important touseadvertising services to reach targeted consumers, such as Facebook ads, Instagram ads, and Google ads. Azhar Farm needs to consider getting rabbit fillets to be better known, and more people are interested in making purchases.

5. Product connector to the Supermarket

In order for rabbit fillets to be sold in supermarkets, resources are needed to manage them. In addition, special licenses and standards are needed by partners.

\section{Customer Relationship}

Things that can be considered in this block include:

Special personal assistance for regular customers. This assistance is used to receive constructive complaints and suggestions. It is necessary to consider online, offline, complaint, and catalog request service centers by consumers in one service. The service must have a good response so that many customers can easily communicate; also, the opportunity to buy becomes higher.

\section{Open a discussion forum for potential customers}

It is necessary to consider creating a discussion forum with various applications. The discussion forum will provide information and knowledge about Azhar Farm and fillets so that customers do not hesitate to buy.

2. Delivery for loyal customers

Azhar Farm can use the service if it has a departmentwhich markets the product. The service will provide advantages for Azhar Farm to compete in the rabbit fillet business.

3. Guarantee and discounts at a certain time.

Giving discounts at certain times to attract larger customers, so it needs to consider the estimated costs and production results. Guarantees are needed by consumers to guarantee that what they ordered is what they expected.

\section{Revenue Streams}

Considerations for increasing revenue streams are:

1. Sales with a variety of weights and prices.

Consumers have different choices by considering various aspects, such as price and quantity. Azhar Farm needs to directly consider variations in weight and sales prices for middle and upper target consumers.

2. Processing Other Products Besides Rabbit Meat

Another alternative that can be applied is to collaborate in the processing of livestock products other than fillets. In rabbit farms, there are fur, urine, and feces that can be processed and packaged to produce other income apart from selling rabbit fillets.

\section{Key Activities}

According to (Lamarque, 2005) in order for an organization to continue to survive, it must have different key activities with competitors or may have the same key activities with competitors but in different ways. There are activities to multiply production and expand marketing are:

1. Technology research anddevelopment

It is necessary to consider research in the process of rapid bodyweight growth. In one rabbit weightsin accordance with consumer needs, while the development of technology needs a temperature control system of the cage to prevent disease in rabbits.

2. Partnerships

The expansion of marketing targets requires continuity in production. One of the ways to consider raising into markets and populations through a rabbit fillet product is building and utilizing an alliance of trading partners.

3. Marketing Specific Research

Consumer demand tends to vary and change suddenly, so it needs to be predicted 
and anticipated through the provision of human resources aimed at making the rabbit fillets produced relevant to market demand and needs.

\section{Key Resources}

Resources considered in business for broad and sustainable marketing are:

1. Physical resources

Refrigerated vehicles need to be added so that the products sent are not easily contaminated and fresh when the product arrives at the customer's home. It also needs to consider the office to carry out various administrative activities, evaluate the system and marketing team to manage business outside the area of farm owned.

2. Financial resources

It is necessary to carry out calculations to support the procurement of physical and human resources so as not to burden and facilitate this business to achieve the desired vision and mission.

\section{Human resources}

Resources work to achieve marketing targets in accordance with the intended marketing segmentation

\section{Key Partnerships}

Partnerships that can be considered are:

1. Online marketing specialist partners

This partner is chosen as an alternative if the addition of HR is considered financial burdens.

2. Production partners in various regions

This method is carried out to support the availability of products in various regions. Rabbit fillet products currently have an exclusive impression that only exists in certain regions. The expansion of partners should be raised, so that rabbit fillets are easy to find in various regions.

3. Business Consultant

Consultants are needed to know the rules and legal products that govern the circulation of a product. To anticipate unwanted things, it would be better for Azhar Farm to consider using consultants so that the rabbit fillet products sold are legally determined by the government. To save costs can utilize consultants who come from government institutions.

\section{Cost Structure}

According to Qastharin (2016) cost structure is all costs incurred to run a business. As for what Azhar Farm can consider are:

1. Salary for additional employees

The addition of human resources in managing marketing will certainly increase expenditure. Azhar Farm needs to consider the effectiveness and optimization of production can be achieved with steps that do not burden the company.

2. Licensing and promotional costs

Licensing fees for legality and distribution permits must be ready because Azhar Farm is a farm that will continue to grow. Promotional costs are also needed to circulate the product widely.

\section{CONCLUSIONS}

Azhar Farm develops business from upstream to downstream starting from breeding, feed making,cultivating, harvesting, slaughtering, processing,and marketing rabbit fillets. Marketing businesses using B2B and opening partnerships to expand the market. Azhar Farm implements BMC. The results of the analysis need to make improvements in order to compete to expand the marketand maintain stability in the business. Improvements to the business model can be implemented in Customer Segments, Customer Relationships, Value Propositions, Channels, Revenue Streams, Key Activities, Key Partners, Resources, and Cost Structure.

\section{REFERENCES}

Badan Pusat Statistik. (2016). Populasi Kelinci di Kota Batu, Jawa Timur.

Lamarque, E. (2005). Identifying key activities in banking firms: a competence-based analysis. Journal of Emerald Group Publishing Limited, 10(7), 29-47. https://doi.org/10.1016/ 
S0749-6826(04)07002-7

Moleong, L. J. (2018). Metodologi Penelitian Kualitatif, cet. In XI. Bandung: PT Remaja Rosdakarya. PT Remaja Rosdakarya.

Morris, L. (2013). Business model warfare: the strategy of business breakthroughs. An Innovation Labs White Paper,prepared dan published jointly with A-CASA, The University of Pennsylvania, 1(1), 13-37. https://doi. org/10.5278/ojs.jbm.v1i1.617

Müller, R. M., Kijl, B., \& Martens, J. K. J. (2011). A Comparison of interorganizational business models of mobile app stores: there is more than open vs. closed. Journal of Theoretical and Applied Electronic Commerce Research, 6(2), 13-14. https://doi.org/10.4067/S0718-18762 011000200007

Osterwalder, A., \& Pigneur, Y. (2012).
Business Model Generation. PT Elex Media Komputindo.

Qastharin, R. (2016). Business model canvas for social enterprise. Journal of Business and Economics, 7(4), 627-637.

Rangkuti, F. (2005). Analisis SWOT Teknik Membedah Kasus Bisnis. PT Gramedia Pustaka Utama.

Solihah, E., Hubeis, A. V. S., \& Maulana, A. (2016). Analisis model bisnis pada $\mathrm{knm}$ fish farm dengan pendekatan business model canvas (BMC). Jurnal Sosial Ekonomi Kelautan Dan Perikanan, 9(2), 185-194. https://doi. org/10.15578/jsekp.v9i2.1220

Supranto, J. (1997). Pengukuran Tingkat Kepuasan Pelanggan dengan Analisis SWOT. Rineka Cipta.

Wheelen, T. L., \& Hunger, J. D. (2010). Strategic Management and Business Policy: Achieving Sustainability. Prentice Hall. 